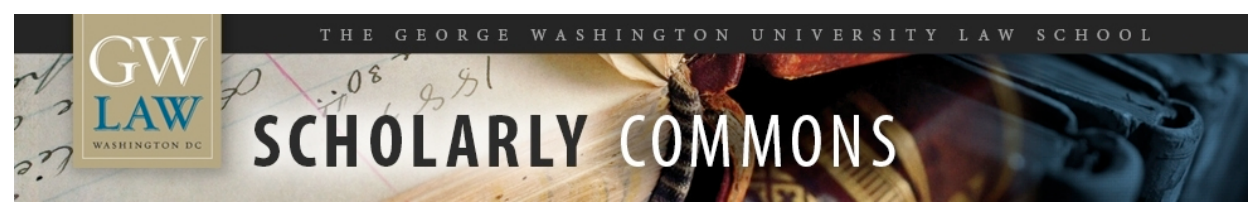

\title{
The Troublesome Inheritance of Americans in Magna Carta and Trial by Jury
}

\author{
Renée Lettow Lerner \\ George Washington University Law School, rlerner@law.gwu.edu
}

Follow this and additional works at: https://scholarship.law.gwu.edu/faculty_publications

Part of the Law Commons

\section{Recommended Citation}

Lerner, Renee Lettow, The Troublesome Inheritance of Americans in Magna Carta and Trial by Jury (2016). Renée Lettow Lerner, The Troublesome Inheritance of Americans in Magna Carta and Trial by Jury, in Magna Carta and its Modern Legacy 77-98 (Robert Hazell and James Melton eds., Cambridge University Press 2015). ; GWU Law School Public Law Research Paper No. 2016-21; GWU Legal Studies Research Paper No. 2016-21. Available at SSRN: http://ssrn.com/abstract= http://ssrn.com/ abstract $=2797371$

This Chapter is brought to you for free and open access by the Faculty Scholarship at Scholarly Commons. It has been accepted for inclusion in GW Law Faculty Publications \& Other Works by an authorized administrator of Scholarly Commons. For more information, please contact spagel@law.gwu.edu. 


\title{
5 \\ The Troublesome Inheritance of Americans in Magna Carta and Trial by Jury
}

\author{
Renée Lettow Lerner
}

The United States is famously a nation founded on universal principles, not on blood. At least, that is the theory proclaimed today. Many American colonists and revolutionaries had a different view: they thought of their rights as an ancient inheritance based on their blood. Instead of declaring the universal rights of man, as French revolutionaries later did, Americans often insisted on their inheritance as Englishmen. At every opportunity in proclaiming their liberties, they harped on their ancestors and their descendants - fathers, children, posterity and so on. For the most part, they did not mean spiritual ancestors or descendants; they meant flesh and blood. ${ }^{1}$ The transformation from blood descent to spiritual descent came later, expressed most eloquently by Abraham Lincoln drawing on the words of the Declaration of Independence. ${ }^{2}$

1 John Jay in The Federalist No. 2 emphasised the common blood of Americans as a basis for forming the new nation: 'Providence has been pleased to give this one connected country to one united people - a people descended from the same ancestors, speaking the same language, professing the same religion, attached to the same principles of government, very similar in their manners and customs, and who, by their joint counsels, arms, and efforts, fighting side by side throughout a long and bloody war, have nobly established their general liberty and independence.' The Federalist No. 2 (John Jay) (1787), reprinted in Clinton Rossiter (ed.), The Federalist Papers (New York: Penguin, 1961), 38. The preamble to the U.S. Constitution also uses the language of descent: "We the people of the United States, in order to ... secure the blessings of liberty to ourselves and our posterity, do ordain and establish this Constitution for the United States of America.'

2 Abraham Lincoln, Speech at Chicago, Illinois, 10 July 1858, in Roy P. Basler et al. (eds.), The Collected Works of Abraham Lincoln, 9 vols. (New Brunswick, NJ: Rutgers University Press, 1953), vol. II, 499-500.

'We find a race of men living in that day [1776] whom we claim as our fathers and grandfathers. ... We have besides these men - descended by blood from our ancestors among us perhaps half our people who are not descendants at all of these men, they are men who come from Europe - German, Irish, French and Scandinavian - men that have come from Europe themselves, or whose ancestors have come hither and settled here, finding themselves our equals in all things. If they look back through this history to trace their 
At the time of independence, many Americans believed that this inheritance was unchanging from ancient times, from 'time immemorial'. No king or parliament could rightfully alter this birthright of the English people. The body of this inheritance was the fundamental laws of England, especially as expressed in Magna Carta. Magna Carta was pre-eminent as an embodiment of the fundamental law because its antiquity demonstrated the endurance of the inheritance. To early Americans, Magna Carta not only symbolised the general idea of a government constrained by a formal charter, but it described specific rights. The right Americans most often invoked in connection with the Great Charter was the right to trial by jury. The barons at Runnymede certainly did not intend to enshrine common law trial by jury, which hardly existed in 1215. In linking Magna Carta with jury trial, Americans were following a line of thought that had begun in the late Tudor period with antiquarians interested in tracing the ancient constitution of England, in many cases back to the Anglo-Saxons. Edward Coke and others in the seventeenth century celebrated this link between Magna Carta and jury trial in their battles against royal prerogative.

Over time, trial by jury proved to be a troublesome inheritance. Americans of the colonial and revolutionary era exalted the jury as a means of furthering self-governance and nullifying despised British laws. In their enthusiasm for the jury, Americans put the translated words of Article 29 of Magna Carta directly into many of their new constitutions. ${ }^{3}$ After Americans had created representative republics, however, the self-governing and law-nullifying functions of the jury came to seem unnecessary at best and often harmful. Increasingly, judges and legislators criticised the jury for its expense, delay and unpredictability.

The tone and content of judicial opinions reflected this change in attitudes towards the jury. Judicial opinions in the early republic continued the colonial and revolutionary rhetoric of an ancient blood inheritance in Magna Carta

connection with those days by blood, they find they have none, they cannot carry themselves back into that glorious epoch and make themselves feel that they are part of us, but when they look through that old Declaration of Independence they find that those old men say that "We hold these truths to be self-evident, that all men are created equal," and then they feel that that moral sentiment taught in that day evidences their relation to those men, that it is the father of all moral principle in them, and that they have a right to claim it as though they were blood of the blood, and flesh of the flesh, of the men who wrote that Declaration, and so they are. That is the electric cord in that Declaration that links the hearts of Patriotic and liberty-loving men together, that will link those patriotic hearts as long as the love of freedom exists in the minds of men throughout the world.'

3 I will refer to this passage as Article 29, following the reissuance of 1225 rather than the original version of 1215, in which the passage appears as Article 39. Blackstone and many American sources use the numbering of the reissuance of 1225 . 
and interpreted the language of the Great Charter as a source of specific rules concerning the jury. In the nineteenth century, judges still praised Magna Carta but dropped references to ancestors and inheritance. Magna Carta lost its specific import and became a vague symbol of limited government. Judges and legislators gradually curtailed the power of juries, but they were never able fully to replace them. The fate of trial by jury in America suggests the hazards of enshrining certain specific procedural rights in constitutions. England, with the flexibility of an unwritten constitution, was able effectively to abolish the civil jury and to substitute bench trial, a form of adjudication more suited to a commercial age.

\section{THE ANGIENT RIGHTS OF ENGLISHMEN AND THE INHERITANCE OF AMERICANS IN MAGNA CARTA}

Edward Coke, writing amid the constitutional controversies of the early seventeenth century, was the most influential exponent of the idea of an English inheritance based on descent and consisting of 'fundamental laws'. ${ }^{4}$ In Coke's view, this inheritance was static and from time immemorial: it preceded the Norman Conquest and endured to Coke's day. ${ }^{5}$ According to the fundamental laws, expressed in Magna Carta and other sources, the king could not take property from or imprison his subjects without due process of law. The law of the land specified what process was due, and its most important component was the common law of England. ${ }^{6}$

English speakers in the seventeenth and eighteenth centuries held different views about the extent to which these rights applied outside of England. Although Coke himself did not believe that the full panoply of rights extended beyond England, English settlers in overseas colonies made the argument that they did. ${ }^{7}$ Colonial charters encouraged this belief. The first charter to the

4 Edward Coke, The Reports of Sir Edward Coke, Knt. In Thirteen Parts Reprinted in New Edition, 13 vols. (London: Joseph Butterworth and Son, 1826), vol. V, v (Preface) (first published 1605); Edward Coke, Commons Debates 1628 (19 March-April 1628), Robert C. Johnson and Maija Jansson Cole (eds.), 4 vols. (New Haven: Yale University Press, 1977), vol. II, 357-58; Daniel J. Hulsebosch, "The Ancient Constitution and the Expanding Empire: Sir Edward Coke's British Jurisprudence', Law and History Review 21 (2003): 470.

5 J. G. A. Pocock, The Ancient Constitution and the Feudal Law: A Study of English Historical Thought in the Seventeenth Century (Cambridge: Cambridge University Press, 1957, reissued 1987), 35-36, 42-53, 125-26; Herbert Butterfield, Magna Carta in the Historiography of the Sixteenth and Seventeenth Centuries (Reading: University of Reading, 1969), 11, 22.

6 Edward Coke, The Second Part of the Institutes of the Laws of England (London: M. Fleffer and R. Young, 1642$), 46$.

7 Calvin v. Smith, 7 Coke's Rep. 1a; 77 Eng. Rep. 377, 401 (K.B. 1608); Hulsebosch, 'Ancient Constitution', $456-57$. 
Virginia Company in 1606 declared that every subject of the king living in the British colonies, and 'every of their children' born there, 'shall have and enjoy all Liberties, Franchises, and Immunities ... to all Intents and Purposes, as if they had been abiding and born, within this our Realm of England. .. " The earlier letters patent for the settlement of Virginia issued to Sir Humphrey Gilbert in 1578 and to Sir Walter Raleigh in 1584 contained similar language. 9 And many later charters for the American colonies repeated the language. ${ }^{10}$ In their original context, the clauses probably required equal treatment of the king's natural subjects within England, and possibly within other dominions as well. ${ }^{21}$ At the outer limit, following Coke's most generous writings concerning overseas dominions, the language may have meant that English settlers were entitled to some rights, such as common law tenures, in the colonies. ${ }^{12}$ In the mid eighteenth century, William Blackstone agreed with many English jurists in stating that the common law of England had 'no allowance or authority' in the American colonies; as conquered lands, the American colonies were under the control of Parliament. ${ }^{13}$ American colonists, however, argued that their lands were settled, not conquered, and that they had inherited all the rights of Englishmen. ${ }^{14}$

In this inheritance, Magna Carta had pride of place. As the English constitutional struggles of the seventeenth century continued, Americans added other sources of fundamental law: the Petition of Right of 1628 , the Habeas

8 William MacDonald, Select Charters and Other Documents Illustrative of American History, 1606-1775 (New York: Macmillan Company, 1910), 2.

9 Wilfred J. Ritz, Book Review, "The Road from Runnymede, Magna Carta and Constitutionalism in America, A. E. Dick Howard', Washington and Lee Law Review 26 $(1969): 413-14$

10 See colonial charters collected in Francis N. Thorpe (ed.), The Federal and State Constitutions, Colonial Charters, and Other Organic Laws of the United States of America (Washington, DC: U.S. Government Printing Office, 1909).

11 Hulsebosch, 'Ancient Constitution', 476.

12 Ibid.

${ }^{23}$ William Blackstone, Commentaries on the Laws of England, 4 vols. (Oxford: Clarendon Press, $1765)$, vol. I, $105-06$.

24 The colonists officially declared these views in the Resolutions of the Stamp Act Congress of 1765 and the Declaration and Resolves of the First Continental Congress in 1774. William F. Swindler, "Rights of Englishman" since 1776: Some Anglo-American Notes', University of Pennsylvania Law Review 124 (1976): 1089-90. State legislatures made similar declarations. See, e.g., 'Resolves of the Maryland House of Delegates', printed in the Maryland Gazette ( 3 October 1765), Resolve I: 'Resolved unanimously, That the first Adventurers and Settlers of this Province of Maryland, brought with them, and transmitted to their Posterity, and all other his Majesty's Subjects since inhabiting in this Province, all the Liberties, Privileges, Franchises, and Immunities, that at any Time have been held, enjoyed, and possessed, by the People of Great-Britain.' For a favourable legal analysis of the colonists' position, see Barbara A. Black, 'The Constitution of Empire: The Case for the Colonists', University of Pennsylvania Law Review 124 (1976): 1198-203. 
Corpus Act of 1679, the Bill of Rights of 1689 and the Act of Settlement of 1701. ${ }^{15}$ Magna Carta, however, retained its primary hold on the American imagination. To an astonishing extent, the American colonists printed, distributed, invoked and formally enacted passages from Magna Carta. ${ }^{26}$

Thomas Jefferson's views about the immemorial English constitution, which were widespread among educated colonists, help to explain American devotion to Magna Carta. Jefferson imbibed early - and promoted energetically - the idea that the ancient English constitution and common law were legacies of the Anglo-Saxons. ${ }^{17}$ Central to this ancient English constitution and common law was a primitive democracy supposedly embodied in such 'free' institutions as the folk moot and trial by jury. The Normans imposed feudalism and temporarily deformed these rights, but the ancient rights were restored in Magna Carta. ${ }^{18}$ The constitutional battles of the seventeenth century were further examples of the English asserting their rights against tyrants. American saw themselves in a continuation of this struggle to preserve the ancient rights of Englishmen against usurpers.

As tensions built between the North Atlantic colonies and Britain, American invocations of Magna Carta became more aggressive. On a fourdollar bill printed in Maryland in July 1775, a woodcut depicts the figure of 'Liberty' handing a petition to 'Britannia', who is restrained by King George III, shown trampling Magna Carta (and, for good measure, setting fire to the port of Annapolis). ${ }^{19}$ William Drayton of South Carolina, who had been educated at Westminster School and Balliol College, Oxford, declared his allegiance to the revolutionary cause in a famous pamphlet in 1774:

That the Americans being descended from the same Ancestors with the people of England, and owing fealty to the same Crown, are therefore equally with them, entitled to the common law of England formed by their common Ancestors; and to all and singular the benefits, rights, liberties and claims specified in Magna Charta, in the Petition of Rights, in the Bill of Rights, and

15 Blackstone's list of the fundamental laws of England that comprise 'the absolute rights of every Englishman', in the first chapter of the first book of his Commentaries, includes these and several more. Blackstone, Commentaries, vol. I, 120-41.

16 H. D. Hazeltine, 'Magna Carta and the U.S. Constitution', in Henry E. Malden (ed.), Magna Carta Commemoration Essays (London: Royal Historical Society, 1917); Ritz, Book Review, 409-12; A. E. Dick Howard, The Road to Runnymede: Magna Carta and Constitutionalism in America (Charlottesville: University of Virginia Press, 1968), 13.

${ }^{17} \mathrm{H}$. Trevor Colbourn, The Lamp of Experience: Whig History and the Intellectual Origins of the American Revolution (Chapel Hill: University of North Carolina Press, 1965), 158-84; Stanley R. Hauer, 'Thomas Jefferson and the Anglo-Saxon Language', PMLA 98 (1983): 880-81. Hauer, 'Thomas Jefferson', 880.

19 Four-dollar-bill, Maryland Provincial Currency, issued 26 July 1775, Maryland State Archives, Annapolis, MD, Vosloh Collection, SC 1267. 
in the Act of Settlement. They being no more, than principally declaratory of the grounds of the fundamental laws of England. ${ }^{20}$

Many Americans claimed they had an inheritance, and were not giving it up without a fight.

Why did Americans make such a fuss over their inheritance, their birthright, in Magna Carta? It meant more to them than the comfort of belonging to an ancient tradition. Magna Carta had come to mean certain general ideas of governance, but also specific rights.

There was, of course, the general idea of Magna Carta as a sort of constitution protecting liberties, a fundamental law that endured. This was the sense in which Governor John Winthrop of Massachusetts used the term when he described the decision to draft a Body of Liberties for the colony, in resemblance to a Magna Carta'. 21 The colonial charters often referred to the "Great Charter' as their model. This idea helped lead to the written constitutions of the independent states and the federal government. Such a fixed law had the virtue of limiting the power of the executive, which could become arbitrary and tyrannical. As Winthrop put it, without such a law, there could be 'great danger to our State in regard that our magistrates for want of positive law in many cases might proceed according to their discretion'. ${ }^{22}$ Magna Carta's origins as a set of concessions from the king and limitations on royal prerogative resonated with Americans even more in the 1760 and 1770 s, because they viewed themselves as engaged in a similar struggle with the Crown. As the revolutionary woodcut described previously suggests - and as the long list of accusations specifically against the King in the Declaration of Independence makes clear - in many American minds, George III had become a proxy for everything wrong with the British government.

But Magna Carta was not only, in the view of Americans, the symbol of general principles of constitutional government and the rule of law. It was also a source of specific rights. Colonial interpretations, sometimes following English ones, could be far from the understanding of the barons at Runnymede. Americans found the principle of no taxation without representation in Magna Carta. ${ }^{23}$ One of the most prominent rights Americans found

20 William Henry Drayton, 'A letter from freeman of South-Carolina, to the deputies of NorthAmerica, assembled in the high court of Congress at Philadelphia' (Charleston: Peter Timothy, 10 August 1774), 11-12. This passage occurs in the section of the pamphlet titled 'The American Claim of Rights', which is sometimes cited as the title of the pamphlet.

23 John Winthrop, The Joumal of John Winthrop, 1630-1649, Richard S. Dunn et al. (eds.) (Cambridge, MA: Belknap Press, 1996), 146.

22 Ibid.

${ }_{23}$ The reasoning of the Maryland House of Delegates in ${ }^{2} 765$, during the Stamp Act controversy, is illustrative. 'Resolves of the Maryland House of Delegates', printed in the Maryland Gazette 
in Magna Carta was that of trial by jury. Article 29 of Magna Carta was printed, invoked and enacted more than any other passage.

No freeman shall be taken and imprisoned or disseised of any free tenement or of his liberties or free customs, or outlawed, or exiled, or in any other way destroyed; nor will we go upon him nor send upon him, except by the lawful judgment of his peers or by the law of the land.

To no one will we sell, to no one will we refuse or delay, right or justice. ${ }^{24}$

During and shortly after the American Revolution, many states put a version of this language into their new constitutions. These states included Virginia (1776), ${ }^{25}$ North Carolina $(1776),{ }^{26}$ Delaware (1776), ${ }^{27}$ Maryland $(1776),{ }^{28}$ New York (1777), ${ }^{29}$ South Carolina $(1778),{ }^{30}$ Massachusetts

( 3 October 1765). First, the House resolved, 'it was granted by Magna Charta, and other the good Laws and Statutes of England', that the subject should not be compelled to contribute to any tax 'not set by common Consent of Parliament'. The charter granted to Lord Baltimore to encourage inmigration to Maryland stated that the king would not lay taxes on the colony. Marylanders had always been governed by laws made by the colonial legislature concerning taxes and internal policy, and therefore they had consented to these laws. The freemen of Maryland were not represented in the British Parliament. The House concluded that only the legislature of Maryland had power to lay taxes on the colony and that any other attempt to do so was 'UNCONSTITUTIONAL, and a direct VIOLATION of the RIGHTS of the FREEMEN of this Province'.

24 Translation in Faith Thompson, Magna Carta: Its Role in the Making of the English Constitution 1300-1629 (Minneapolis: University of Minnesota Press, 1948), 68.

25 Virginia Constitution of $1776, \int 8$ ('no man be deprived of his liberty, except by the law of the land or the judgment of his peers').

26 North Carolina Constitution of $1776, \$$ XII ("That no freeman ought to be taken, imprisoned, or disseized of his freehold liberties or privileges, or outlawed, or exiled, or in any manner destroyed, or deprived of his life, liberty, or property, but by the law of the land.').

27 Delaware Bill of Rights of 1776 ("That every freeman for every injury done him in his goods, lands, or person, by any other person, ought to have remedy by the course of the law of the land, and ought to have justice and right for the injury done to him, freely without sale, fully without any denial, and speedily without delay, according to the law of the land.').

28 Maryland Constitution of $1776, S$ XVII ('That every freeman, for any injury done him in his person or property, ought to have remedy, by the course of the law of the land, and ought to have justice and right freely without sale, fully without any denial, and speedily without delay, according to the law of the land.'); id. $\$$ XXI ('That no freeman ought to be taken, or imprisoned, or disseized of his freehold, liberties, or privileges, or outlawed, or exiled, or in any manner destroyed, or deprived of his life, liberty, or property, but by the judgment of his peers, or by the law of the land.').

29 New York Constitution of $1777, \$ 8$ ('And this convention doth further, in the name and by the authority of the good people of this State, ordain, determine, and declare, that no member of this State shall be disfranchised, or deprived of any the rights or privileges secured to the subjects of this State by this constitution, unless by the law of the land, or the judgment of his peers.').

30 South Carolina Constitution of $177^{8}, \int \mathrm{XLI}$ ("That no freeman of this State be taken or imprisoned, or disseized of his freehold, liberties, or privileges, or outlawed, exiled or in any 
$(1780)^{31}$ and New Hampshire (1784)..$^{32}$ The Northwest Ordinance of 1787 , enacted by the Continental Congress as a basic law for the governance of the Northwest Territories, included the guarantee: 'No man shall be deprived. of his liberty or property, but by the judgment of his peers, or the law of the land.'33 By invoking Magna Carta, Americans made a then-radical idea - the complete independence of former colonies - look like the continuation of an ancient tradition of rights.

\section{ORIGINS OF THE LINK BETWEEN MAGNA CARTA}

AND JURY TRIAL

Americans had English precedent to follow in linking Article 29 with jury trial. The link, however, took centuries to develop. The meaning of Article 29 in 1215 concerned feudal tenures and courts, not common law jury trial. In the conflict-ridden fourteenth century, the passage became associated with certain common law procedures. It was not until the growth of antiquarianism in the late sixteenth century that the passage was connected with jury trial. That connection proved useful to Coke in the constitutional battles of the seventeenth century against the king's prerogative. With Blackstone in the mid eighteenth century, Magna Carta became the triumphant guarantee of jury trial, in effect preserving the voice of the people in legal judgments. ${ }^{34}$

With the language of Article 29, the barons at Runnymede could hardly have intended to guarantee common law trial by jury. Jury trial did not exist for criminal cases in 1215, and only for certain types of civil cases. ${ }^{35}$ 'Judgment of

manner destroyed or deprived of his life, liberty, or property, but by the judgment of his peers or by the law of the land.').

${ }^{3}$ Massachusetts Constitution of 1780 , Art. VII ('And no subject shall be arrested, imprisoned, despoiled, or deprived of his property, immunities, or privileges, put out of the protection of the law, exiled, or deprived of his life, liberty, or estate, but by the judgment of his peers, or the law of the land.').

${ }^{32}$ New Hampshire Constitution of $1784, \int 15$ ('And no subject shall be arrested, imprisoned, despoiled, or deprived of his property, immunities, or privileges, put out of the protection of the law, exiled or deprived of his life, liberty, or estate, but by the judgment of his peers or the law of the land.').

33 Northwest Ordinance, Art. II (13 July 1787).

34 Natalie Riendeau's chapter in this volume (Ch. 11) discusses this sort of myth-making concerning Magna Carta, and Craig Lerner's chapter (Ch. 8) describes the U.S. Supreme Court creating a recent myth about Magna Carta.

35 Frederick Pollock and Frederic W. Maitland, The History of English Law before the Time of Edward I, 2nd ed., 2 vols. (Cambridge: Cambridge University Press, 1898), vol. I, 144-49, 173; William S. McKechnie, Magna Carta: A Commentary on the Great Charter of King John, and ed. (Glasgow: James Maclehose and Sons, 1914), 134; John H. Langbein, Renée Lettow Lerner and Bruce P. Smith, History of the Common Law: The Development of Anglo-American Legal Institutions (New York: Aspen Publishers, 2009), 58-64, 97-104. 
his peers,' per judicium parium, appears to have meant that no one could be tried by his inferiors. Rank was determined according to feudal tenures. As a commentator on Magna Carta explained, "the "peers" of a Crown tenant [one who held land directly from the king, typically an earl or a baron] were his fellow Crown tenants, who would normally deliver judgment in the Curia Regis. ${ }^{36}$ The 'peers' of the tenant of a mesne lord - an 'intermediate' lord, who held land from another lord who was not the king - were the fellow tenants of the mesne lord, who gave their opinion in the mesne lord's Court Baron. ${ }^{37}$ King John had often ignored this principle and deprived his enemies of their estates or exiled them by judgment of a tribunal composed of Crown nominees. ${ }^{38}$ The barons did not consider royal judges to be their peers. ${ }^{39}$

In the fourteenth century, certain understandings of Article 29 continued, and some new ones arose, that encouraged a future link to common law trial by jury. During this time of conflict between the Crown and nobles, references to Article 29 were frequent in Parliamentary petitions and statutes. Parliament enacted a later much-celebrated series of statutes referring to Magna Carta and confirming that a trial observing lawful procedures should take place before judgment, which in turn was necessary before execution. ${ }^{4}$ The term 'freeman' was expanded to 'anyone'. ${ }^{4}$ The term 'law of the land' became interchangeable with the new phrase 'due process of law'.42 Due process of law was understood to include an indicting jury and procedure by original writ, and to limit the jurisdiction of prerogative courts. ${ }^{43}$

Beginning in the sixteenth century, English writers explicitly linked the phrase 'judgment of his peers' to jury trial and described this right as an ancient inheritance. The first to do so in print appears to have been William Lambarde in his Eirenarcha of $1581 .{ }^{44}$ Lambarde was a barrister-antiquarian and a collector of Anglo-Saxon laws. In Eirenarcha, an enduringly popular

${ }^{6}$ McKechnie, Magna Carta, 378.

37 This principle seems to have extended to Jews, foreign merchants, Welshmen and possibly Lord Marchers (lords given special powers to govern troublesome areas such as Wales). Ibid., 378-79. In accord with this principle, in 1302 a knight accused of a felony objected to his trial by a jury because they were not his peers. The court agreed, and a jury of knights was substituted. Y.B. 30 \& 31 Ed. I, 531 (R.S. 1302). A bishop made a similar complaint, and the judges are quoted as saying, 'this challenge is usual, when a peer of the Realm is a party. ...'Y.B. 12 \& 13 Ed. III, 290-91. Both these cases are discussed in Thompson, Magna Carta, 70.

$3^{8}$ McKechnie, Magna Carta, $37^{8}$.

39 Pollock and Maitland, History of English Law, vol. I, 173.

405 Edw. III, c. 9 (1331); 25 Edw. III, st. 5, c. 4 (1352). On this series of statutes, see Thompson, Magna Carta, 90-94.

$4125 \mathrm{Edw}$. III, st. 5, c. 4 (1352); 28 Edw. III, c. 3 (1354).

$4228 \mathrm{Edw}$. III, c. 3 (1354); $42 \mathrm{Edw}$. III, c. 3 (1368).

4342 Edw. III, c. 3 (1368).

44 See Thompson, Magna Carta, 185-86. 
manual for justices of the peace, Lambarde described jury trial in criminal cases as 'according to the antient libertie of the Lande, whereunto everie Free bourne man thinketh himself inheritable. And thereupon it is named (Mag. Chart. cap. 29) Legale iudicium parium suorum, the lawfull iudgment of a mans own Peeres, or Equalles. ...'45 Eirenarcha was familiar to Americans, being found in the libraries of Thomas Jefferson and George Wythe, among others. ${ }^{46}$

Coke and John Selden continued the identification of Article 29 of Magna Carta with jury trial in the seventeenth century. This link aided Coke's quest, in his later career, to strengthen the common law courts and to limit Chancery and the other prerogative courts, which sat without juries and were more directly subject to royal control. ${ }^{47}$ As Coke envisioned it, 'Upon this [Article], as out of a roote, many fruitfull branches of the Law of England have sprung. ${ }^{48}$ Coke explained this passage as requiring before seizure of a person's property 'the lawfull judgement, that is, verdict of his equals (that is, of men of his own condition) or by the Law of the Land (that is, to speak it once for all) by the due course, and processe of Law'.49 Selden, in his commentaries on Fortescue's work on English law, described judicium parium as 'legal judgment of his peers or men of his condition, that is by jury'..$^{\circ}$

In the mid eighteenth century, Blackstone exalted the identification of Article 29 with the jury. He explicitly praised the jury for tempering the class biases of judges. ${ }^{51}$ In invoking Magna Carta, Blackstone created for the jury a title it retained through the centuries in America - and which continues in use today. 'In magna carta it [the jury] is more than once insisted on as the principal bulwark of our liberties; but especially by chap. $29 .{ }^{52}$ Blackstone lavished praise on the jury, ${ }^{53}$ and in this he has been eagerly followed ever since by American politicians, lawyers and judges.

45 William Lambarde, Eirenarcha, or, The Office of Justices of Peace (London: Ra. Newbery and H. Bynneman, 1581), 436-37.

46 See http://lawlibrary.wm.edu/wythepedia/index.php/Eirenarcha.

47 Butterfield, Magna Carta, 11, 18-19; Pocock, Ancient Constitution, 44-46; Maurice Ashley, Magna Carta in the Seventeenth Century (Charlottesville: University Press of Virginia 1965), 10-11.

$4^{8}$ Coke, Second Institutes, 46.

49 Ibid.

5o John Fortescue, De Laudibus Legum Angliae, with notes by John Selden (London: 1672), ch. xxvi, quoted in Thompson, Magna Carta, 242.

51 Blackstone, Commentaries, vol. III, 379.

52 Ibid., 350 (emphasis added).

53 See, e.g., ibid. ('a privilege of the highest and most beneficial nature'); ibid., 355 ('how admirably this constitution [trial by jury] is adapted and framed for the investigation of truth, beyond any other method of trial in the world'); ibid., 379 ('the glory of English law'; 'the most transcendent privilege which any subject can enjoy'). 


\section{MAGNA CARTA AND JURIES IN COLONIAL AMERICA \\ AND THE NEW REPUBLIC}

We need to see through the rhetoric surrounding the jury right in the eighteenth century and try to understand what this devotion to the jury meant concretely. As with devotion to Magna Carta, there were general principles but also specific issues. At the heart of American fervour about the jury was that institution's ability to nullify laws. The unpopular laws that juries nullified varied over time, from seditious libel and customs laws in the colonial period to private debts in the early republic. American independence and republicanism, however, resolved the imperial tensions that had given rise to expansive claims for jury law-finding in late colonial times. After the first few decades of independence, judges and legislators increasingly criticised the expense and unpredictability of civil juries.

Concerning the criminal jury, as Alexander Hamilton remarked in The Federalist No. 83, Americans universally agreed that the institution was necessary to prevent despotism. ${ }^{54}$ Especially, many Americans prized the criminal jury for its ability to nullify unpopular laws. One of the most prominent examples was the acquittal of the printer John Peter Zenger in 1736 in his trial for seditious libel of the colonial governor of New York. ${ }^{55}$ American juries either refused to indict or acquitted so often in cases of seditious libel that the law essentially became a dead letter in the colonies. ${ }^{6}$

At the time of the revolution, American colonists' experience with civil juries, as with criminal juries, led many to value the institution as a means of nullifying the law. In the case of Ening $\nu$. Cradock [1761], for example, a Massachusetts merchant sued a customs inspector for trespass and won a large verdict from a jury. ${ }^{57}$ The royal governor of Massachusetts, Francis Bernard, complained to a former governor that a custom house officer has no chance with a jury, let his cause be what it will'. ${ }^{8}$ Bernard warned his superiors in

54 The Federalist No. 83 (Alexander Hamilton) (1788), reprinted in Rossiter (ed.), 499.

55 James Alexander, 'A Brief Narrative of the Case and Trial of John Peter Zenger' (1736), in Stanley N. Katz (ed.), The Case and Trial of John Peter Zenger (Cambridge, MA: Harvard University Press, 1989), 78, 100-01.

56 Langbein, Lerner and Smith, History of the Common Law, 478-79.

57 Governor Francis Bernard to the Lords of Trade, 6 August 1761, 2 Bernard Papers 46, 47, reprinted in Josiah Quincy, Samuel Miller Quincy and Horace Gray (eds.), Reports of Cases Argued and Adjudged in the Superior Court of Judicature of the Province of Massachusetts (Boston: Little, Brown, and Company, 1865), 553-55.

${ }^{8}$ Governor Francis Bernard to Thomas Pownall, 28 August 1761 , reprinted in Quincy, Reports of Cases, 555-56. 
London that such verdicts effectively overturned judgments of the Court of Admiralty - which sat without juries - and nullified customs laws. ${ }^{59}$ Another colonial governor of Massachusetts wrote that 'a trial by jury here is only trying one illicit trader by his fellows, or at least by his well-wishers'. ${ }^{\circ}$ Colonists viewed the jurisdiction of the juryless admiralty courts, which prevented nullification of customs laws, as a major grievance. In response to the Stamp Act of 1765 , delegates from nine of the thirteen colonies met in New York the same year, a meeting known as the Stamp Act Congress. ${ }^{6}$ They adopted a Declaration of Rights and Grievances, including ' $[t]$ hat trial by jury is the inherent and invaluable right of every British subject in these colonies.... [The Stamp Act] and other acts, by extending the jurisdiction of the courts of admiralty beyond its ancient limits, have a manifest tendency to subvert the rights and liberties of the colonists. ${ }^{162}$ The Declaration of Independence listed as a reason for separation: 'For depriving us, in many cases, of the benefits of trial by jury. ${ }^{6}{ }^{6}$ The British government, in the view of many Americans, was depriving them of their birthright to jury trial in Magna Carta and thus preventing them from nullifying the hated customs laws. This view accounts for the immediate insertion of the language of Article 29 of Magna Carta into the new state constitutions.

Once the republican governments took power, however, jury nullification became deeply problematic. The people now had a say in the making of laws; they had consented to them. Why should twelve citizens have the power to nullify laws enacted by a legislature elected by the entire people? Furthermore, legislatures followed a process for enacting laws carefully specified in a written constitution, itself ratified by the people.

The Federalists publicly began to express doubts about the civil jury. The federal Constitution, drafted in 1787 , did not include a right to civil jury trial in federal courts. In explaining the reasons to the public, Alexander Hamilton questioned civil jurors' ability to decide complicated issues of law and fact

59 Governor Francis Bernard to the Lords of Trade, 6 August 1761, reprinted in Quincy, Reports of Cases, 554 ('Your Lordships will perceive that these actions have an immediate tendency to destroy the Court of Admiralty and with it the custom house, which cannot subsist without that Court.').

60 Governor William Shirley, quoted in Stephen Botein, Early American Law and Society (New York: Knopf, 1983), 57.

615 Geo. 3, c. $12(1765)$; C. A. Weslager, The Stamp Act Congress: With an Exact Copy of the Complete Joumal (Newark: University of Delaware Press, 1976), 6.

62 Resolves of the Stamp Act Congress, October 1765, in Weslager, Stamp Act Congress, 126. See also Drayton, 'A letter from freeman of South-Carolina', 13 (complaining of the powers of the admiralty courts).

63 Declaration of Independence (4 July 1776), reprinted in Thorpe, Federal and State Constitutions, vol. I, 5. 
correctly. ${ }^{64}$ The Anti-Federalists countered with a variety of arguments. The legislature might be captured by special interests and legislate against the good of the whole. ${ }^{65}$ The executive might use its power to reward friends or to punish political enemies. ${ }^{6 \sigma}$ The civil jury, in both England and America, had proved useful in awarding damages in trespass suits against executive offcials. ${ }^{67}$ The judiciary might be corrupt or biased in favour of elites. ${ }^{68}$ The jury could check all of these abuses.

The specific issue underlying these arguments was the civil jury's ability to nullify debts. Debtors were a powerful political force soon after the revolution. State legislatures passed various laws that made it easier for debtors to escape creditors' demands. ${ }^{6}$ In addition, state juries were sympathetic to debtors. ${ }^{70}$ In contrast, the new federal Constitution contained various provisions that favoured creditors. ${ }^{71}$ (Federalists generally thought it imperative to repay debts, for the credit and prosperity of the new nation. ${ }^{72}$ Anti-Federalists such as Patrick Henry of Virginia avoided openly praising the civil jury for nullifying debts, but they made the connection clear in their speeches. ${ }^{73}$ AntiFederalist protest succeeded in persuading a reluctant James Madison to draft a federal Bill of Rights, including a right to civil jury trial in the Seventh Amendment. Madison had argued against the need for a federal right to civil jury trial in the Virginia ratifying convention. ${ }^{74}$ In drafting what became the

${ }_{64}$ The Federalist No. 83 (Alexander Hamilton) (1788), reprinted in Rossiter (ed.), 469-71.

65 Matthew P. Harrington, 'The Economic Origins of the Seventh Amendment', Iowa Law Rev. 87 (2001): 186 .

66 Ibid., $185-86$.

67 Bradford R. Clark, 'The Eleventh Amendment and the Nature of the Union', Harvard Law Review 123 (2010): 1905-06; Akhil Reed Amar, 'Fourth Amendment First Principles', Harvard Law Review 107 (1994): 757, 775-78; David E. Engdahl, 'Immunity and Accountability for Positive Government Wrongs', University of Colorado Law Review 44 (1972): 1, 14, 19.

68 See Max Farrand, The Records of the Federal Convention of 1787,3 vols. (New Haven: Yale University Press, 1911), vol. II, 587 (argument of Elbridge Gerry); Harrington, 'Economic Origins', 187 (quoting arguments of Anti-Federalists). Alexander Hamilton agreed that checking the possible corruption of judges was the strongest argument in favour of civil juries. The Federalist No. 83 (Alexander Hamilton) (1788), reprinted in Rossiter (ed.), 500. He observed, however, that jurors could be corrupted as well as judges. Ibid., 500-01. Blackstone's principal argument in favour of the jury was that judges might be biased towards elites. Blackstone, Commentaries, vol. III, 379-80.

69 Charles W. Wolfram, 'The Constitutional History of the Seventh Amendment', Minnesota Law Review 57 (1973): 639, 674-75; Harrington, 'Economic Origins', 170-72.

70 Harrington, 'Economic Origins', 173-74; Wolfram, 'Constitutional History', 675-76.

71 These included the Contracts Clause, which forbids the states to enact laws impairing the obligation of contracts. U.S. Const. Art. I, $\$ 10$.

72 Harrington, 'Economic Origins', 173-76.

73 See, e.g., Jonathan Elliot (ed.), The Debates in the Several State Conventions of the Adoption of the Federal Constitution, and ed., 5 vols. $(1836)$, vol. III, 317-19.

74 Elliot, Debates, vol. III, 534-38. 
Seventh Amendment, he studiously avoided glorifying the civil jury and therefore made no direct reference to Magna Carta.

\section{MAGNA CARTA AND JURIES IN AMERICAN JUDICIAL OPINIONS}

The Federalist concerns about the jury presaged the attitudes of many later legislators and judges in the United States. Politicians and judges continued and continue - to praise the jury in Blackstone's extravagant terms and to exalt Magna Carta as the guarantee of this liberty. Year by year, however, they whittled the jury away. This erosion was especially true of the civil jury. At the founding of the American republic, the jury had been a political institution, as Tocqueville famously described it. ${ }^{75}$ In the nineteenth century, however, many Americans in all areas wanted predictable, uniform legal rules that would help promote commercial development. ${ }^{6}$ Use of civil juries could lead to unlawful, unpredictable results that undermined the authority of legislatures and courts, and thwarted the ability to plan and carry out actions. Besides, the expense and inconvenience of jury trial was great. 77 The jury began to be regarded more as a judicial institution than as a political one, and as a judicial institution the jury fell short.

We see this shift in attitudes towards the jury in the opinions of state and federal courts. Because Article 29 of Magna Carta had been enshrined in many state constitutions, it was formally the law. Most courts could avoid having to interpret this thirteenth-century language, because almost all state

75 Alexis de Tocqueville, Democracy in America, J. P. Mayer (ed.), George Lawrence (trans.) (New York: Harper Perennial, 1969), 270-76.

$7^{6}$ In the North, judges such as James Kent, Joseph Story, Isaac Parker and Jeremiah Smith worked to create uniform national private law that furthered commercial development and constrained juries. Daniel J. Hulsebosch, Constituting Empire: New York and the Transformation of Constitutionalism in the Atlantic World, 1664-1830 (Chapel Hill: University of North Carolina Press, 2005), 286-87; John P. Reid, Controlling the Law: Legal Politics in Early National New Hampshire (DeKalb: Northern Illinois University Press, 2004), 107, 115-30; John H. Langbein, 'Chancellor Kent and the History of Legal Literature', Columbia Law Review 93 (1993): 566-69; Renée B. Lettow, 'New Trial for Verdict against Law: Judge/Jury Relations in Early Nineteenth-Century America”, Notre Dame Law Review 71 (1996): 519-21. In the South, judges such as Joseph Lumpkin of Georgia and Hamilton Gamble of Missouri wanted to encourage commercial and industrial development and predictable legal rules. See Paul D. Hicks, Joseph Henry Lumpkin: Georgia's First Chief Justice (Athens: University of Georgia Press, 2002), 63-72; Timothy S. Huebner, The Southem Judicial Tradition: State Judges and Sectional Distinctiveness, 1790-1890 (Athens: University of Georgia Press, 1999), 73-74, 81-86; Dennis K. Boman, Hamilton Gamble: Dred Scott Dissenter and Missouri's Civil War Govemor (Baton Rouge: Louisiana State University Press, 2006), 18-22.

77 Renée Lettow Lerner, "The Failure of Originalism in Preserving Constitutional Rights to Jury Trial', William and Mary Bill of Rights Joumal 22 (2014): 846-50. 
constitutions had explicit guarantees of jury trial in addition to the language from Article 29. ${ }^{78}$ The state jury trial rights typically used the language of preservation: 'The right of trial by jury shall remain inviolate. 79 Many courts paused to heap praise on Magna Carta when interpreting the jury clauses in their state constitutions, but there was seldom need to address Article 29 extensively. Maryland, however, did not have a separate jury right apart from the language of Magna Carta, so courts had to interpret it. A few courts from other states - particularly those rare courts that found violations of the jury right - also analysed the language of Magna Carta in their opinions.

I will focus on two opinions that discussed Magna Carta language extensively as part of their holdings. The first was the opinion of the Supreme Court of South Carolina in 1794 in Zylstra v. Corporation of Charleston, based on a criminal case. ${ }^{80}$ The second was the opinion of the U.S. Supreme Court in 1819 in Bank of Columbia v. Okely, a case of debt to a bank. ${ }^{8 x}$ The differences between the two opinions reflect changing attitudes towards the jury.

\section{A CASE IN THE EARLY REPUBLIC}

Zylstra illustrates the strong echoes of the immemorial English constitution, the birthright of Americans, in the early republic. In Zylstra, the wardens' court of the city of Charleston had convicted Zylstra of violating a city ordinance forbidding keeping a tallow-chandler's shop within the city. ${ }^{82}$ The wardens' court, which sat without a jury, fined Zylstra $£_{100}$. Zylstra then sued for a writ of prohibition in the Supreme Court of South Carolina, claiming violation of the right to jury trial. Zylstra's counsel argued the point vigorously, claiming that a power to levy such a substantial fine vested in judges alone "had a tendency to deprive a citizen of the inestimable trial by jury, the birthright of every citizen, secured to him by magna charta and our excellent constitution'. ${ }^{83}$ This was the traditional language of inheritance of rights, familiar from the colonial and revolutionary period, and now carried into the new republic.

The Supreme Court of South Carolina issued the prohibition. The most elaborate opinion, by Judge Thomas Waties, considered in detail the meaning

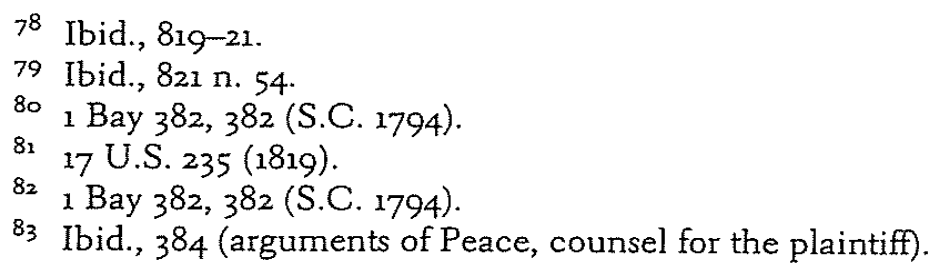


of language from Magna Carta. South Carolina's Constitution of 1790 contained a clause based on Article 29. ${ }^{84}$ The constitution also contained a separate guarantee of jury trial, similar to that of many other states: 'The trial by jury, as heretofore used in this state, shall be forever inviolably preserved. ${ }^{85}$ Later judicial opinions about the right to jury trial would rest mainly, if not exclusively, on the specific jury guarantee. There was a difficulty with this line of analysis in Zylstra for a judge determined to find a violation of the right to jury trial. The court of wardens had been created before the South Carolina Constitution of 1790 , and therefore the constitution might be thought to confirm the court's powers. ${ }^{86}$ Judge Waties agreed that this would be a reasonable argument, if the constitution was the first acquisition of the peoples' right of trial by jury. In his view, this was not so.

But the trial by jury is a common law right; not the creature of the constitution, but originating in time immemorial; it is the inheritance of every individual citizen, the title to which commenced long before the political existence of this society; and which has been held and used inviolate by our ancestors, in succession, from that period to our own time. ${ }^{87}$

Here again we see the language of inheritance and ancestors, from Coke's time immemorial. Although the right to trial by jury was not described as a natural right in the universal sense of the French Enlightenment, it was a right of the English people and their descendants in America. Interestingly, Waties gave different reasons for the right in England and America. In England, he wrote, the jury was necessary to control 'the usurpations of the government'; 88 he seemed to refer mainly to the control of the executive, and possibly the legislature. In the republics of the United States, in contrast, the jury's main purpose was to check the judiciary, which might be biased in favour of the rich and powerful. ${ }^{89}$ Nevertheless, the source of the inheritance was the same.

The claim of an ancient inheritance left Judge Waties with the problem of defining the precise scope of this right originating in time immemorial. To elucidate the meaning of the language of Magna Carta, Waties turned to a British author, Francis Stoughton Sullivan. Sullivan's Lectures on the Constitution and Laws of England, with additions by Gilbert Stuart and

84 South Carolina Constitution of 1790 , Art. IX, S 2 ("No freeman of this state shall be in any manner deprived of his life, liberty, or property, but by the judgment of his peers, or by the law of the land.').

85 Ibid., $\$ 6$.

86 Bay, 395 .

87 Ibid.

88 Ibid.

89 Ibid., 396. 
published in London in 1776 , contained a commentary on Magna Carta that Waties regarded as a helpful 'illustration' of Coke's authoritative interpretation of the Great Charter. $9^{\circ}$ Waties seems to have relied on Sullivan rather than on Blackstone in part because Sullivan addressed the language of Magna Carta more specifically and in part because of Blackstone's overly 'high ideas of the omnipotence of parliament'. ${ }^{11}$ (Most American judges were content to rely on Blackstone's similar discussion.) Based on Sullivan's account, Waties described the various cases and courts in which the 'law of the land' permitted judgment without jury trial..$^{92} \mathrm{He}$ concluded that the jurisdiction of the juryless court of wardens could not stretch to this case. ${ }^{93}$ Waties's colleague Judge Elihu Bay, who agreed with Waties's opinion and reported the case, added the comment that the city ordinance was repealed after the decision and that 'no attempt was ever after made to exercise so unwarrantable a jurisdiction'. 94

\section{AN EXAMPLE FROM THE MATURING UNITED STATES}

Later courts did not find limitations on the use of juries to be so unwarrantable. As the republic matured, courts dropped the language of ancestors and rights from time immemorial and focused on efficiency in adjudication. The 1819 opinion of the U.S. Supreme Court in Bank of Columbia v. Okely was widely influential. 95 Okely concerned a summary proceeding; a Maryland statute of 1793 authorised the Bank of Columbia to use a summary proceeding to collect debts owed to it, provided that the notes were made expressly negotiable at the bank at their creation. After an affidavit by the president of the bank, alleging the indebtedness, was filed with the clerk of a court, the assets of the alleged debtor were subject to immediate execution. The alleged debtor could dispute the indebtedness and demand a jury trial on the return of the execution. The preamble to the statute explained, 'It is absolutely necessary that the debts due to the said bank should be punctually paid, to enable the directors to calculate with certainty and precision on meeting the demands that may be made upon them. ${ }^{96}$ The Maryland act became part of the law of the District of Columbia through an act of the U.S. Congress in 1801,

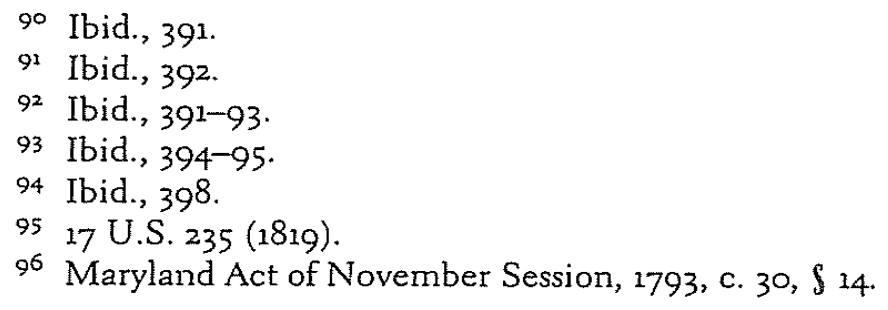


incorporating the laws of Maryland. Okely moved to quash an execution under this provision, because the act violated the rights to jury trial in the Seventh Amendment to the U.S. Constitution and Article 21 of the Maryland Constitution.

In Okely, the U.S. Supreme Court was in the rare position of needing to interpret the language of Magna Carta. Maryland had no specific guarantee of jury trial apart from the language drawn from Magna Carta, and as the U.S. Supreme Court observed, if the statute was void under the constitution of Maryland, its provisions were not incorporated as the law of the District of Columbia. ${ }^{97}$ Justice William Johnson, a native of Charleston, took a different attitude towards Magna Carta than had his fellow South Carolinian Thomas Waties. In his opinion for the court, Justice Johnson wasted no time with the usual fulsome praise of the words of the Great Charter. His tone, indeed, suggested impatience with the volumes spoken and written with a view to their exposition'. ${ }^{8}$ Instead of trying carefully to interpret the words in light of respected scholarly authorities, as Judge Waties had done, Justice Johnson peremptorily declared that the good sense of mankind' had arrived at last at the idea 'that they were intended to secure the individual from the arbitrary exercise of the powers of government, unrestrained by the established principles of private rights and distributive justice'.99 After this vague announcement, Johnson explained that there was nothing left for the defendant to complain of. Because the note was expressly negotiable at the bank at its making, Okely had voluntarily consented to the summary method of proceeding. " $\mathrm{T}] \mathrm{he}$ debtor chose his own jurisdiction', as in an arbitration, and therefore neither the Seventh Amendment nor the Maryland Constitution was violated. In effect, the defendant had waived the right of jury trial before execution. Besides, the defendant could, if he chose, demand a jury trial after execution. The court was apparently not concerned that these summary proceedings created significant obstacles to jury trial. Efficiency in the furtherance of a robust credit system and economy was more important. The case occurred during the financial panic of 1819 , when the credit system in the United States was strained. It seems likely that these practical exigencies encouraged Justice Johnson's dismissive attitude towards the jury right embodied in the Great Charter.

Many American judges continued to hail Magna Carta as 'the great charter of English liberty' in connection with the right to trial by jury, but, as in Okely,

9717 U.S. 242.

98 Ibid., 244 .

99 Ibid. 
allusions to the Charter were vague and did not entail detailed analysis of its meaning. ${ }^{100}$ References to common ancestors and inheritance disappeared. The English and American peoples were thought to be separate. But although they were regarded as separate by the nineteenth century, they were still viewed as traveling parallel paths in the limitation of the jury.

In an opinion in 1841 , Judge Trotter of the Mississippi High Court of Errors and Appeals quoted the U.S. Supreme Court's opinion in Okely. Trotter explained, after the customary praise of Magna Carta, that 'it is not regarded as any infringement of [the English people's] rights thus solemnly pledged, that in the arrangement and distribution of the powers in the several courts which have grown up under the common law in that country, modes of trial in many cases are allowed which dispense with the verdict of a jury'. ${ }^{101}$ Judge Trotter followed Blackstone in declaring that the right to trial by jury is justly regarded as one of the strongest bulwarks of human rights, and is held dear by the people of this country ${ }^{102}$ Nevertheless, the court held that the right could be waived in civil cases.

Chief Justice Joseph Lumpkin of the Georgia Supreme Court, in an opinion in 1848 , went even further. ${ }^{103}$ His opinion included extensive excerpts from the U.S. Supreme Court's opinion in Okely. Lumpkin reported with approval Judge Trotter's praise of Magna Carta and the jury, but like him added that many types of civil cases were tried daily without a jury. ${ }^{104}$ 'Indeed, it is notorious, that modern law reform, both in England, and in this country, seeks, amongst other objects, to dispense, as much as possible with juries."105 He cited as evidence of this trend the provisions for waiver of jury trial in New York's then new Field Code (1848) ${ }^{106}$ and the recent County Courts Act (1846) in England. ${ }^{107}$ Another example was the summary proceeding that was established in the statute whose constitutionality was at issue in the case before the Georgia Supreme Court. Lumpkin and his colleagues held that the proceedings did not violate constitutional rights to civil jury trial. The summary proceeding, Lumpkin explained, promoted the interests both of agriculture

${ }^{100}$ See, e.g., Lewis v. Garrett's Adm'rs, 6 Miss. (5 Howard), 434, 455 (1841).

${ }^{101}$ Ibid.

${ }^{102}$ Ibid., 457.

${ }^{103}$ Flint River Steamboat Co v. Foster, 5 Ga. 194 (1848).

${ }^{104}$ Ibid., 206-07.

105 Ibid., 207.

${ }^{106}$ Ibid. ('A]]s a justification for this change, it is stated that in the city of New York, where the right of election existed as to the mode of trial, 1285 judgments were rendered by the Court in Marine causes without, against 67 upon the verdict of a jury.'). See N.Y. Sess. Laws c. 379, $\int 221$ (1848).

${ }^{107} 5 \mathrm{Ga} .207$. See 9 \& 10 Vict., c. $95(1846)$. On the provisions of the County Courts Act concerning jury trial, see Conor Hanly, "The Decline of Civil Jury Trial in Nineteenth-Century England', Joumal of Legal History 26 (2005): 269-74. 
and commerce ${ }^{108}$ and resulted in 'a vast saving of time, trouble, and expense, to suitors and the country'. ${ }^{109}$ The rhetoric of judges extolling jury trial helped distract attention from the effect of their decisions, which was to limit it. Efficiency in adjudication in order to promote economic growth was more important.

\section{THE FATE OF THE INHERITANCE IN ENGLAND}

England was traveling a similar path, and indeed went further than the United States in limiting the jury. The jury, especially the civil jury, was increasingly viewed in the land of its birth as a wasteful nuisance. By the nineteenth century, English judges had full independence and were believed to be on the whole intelligent, learned and free from corruption. ${ }^{10}$ Under those circumstances, a bench trial seemed preferable to the trouble and expense of collecting lay jurors, trying to explain the facts and law to them, and awaiting their verdict. Jurors almost always followed the judge's hints in his summing up anyway. ${ }^{211}$

In the 1840 s, the English legal profession fired criticism at the jury. ${ }^{112}$ Even Punch joined in, publishing Gilbert à Beckett's The Comic Blackstone in 1846. The most quoted passage, and one singled out for admiration in the United States, was a satire of Blackstone's chapter on the civil jury. Beckett opened his chapter with a warning: 'It is difficult to get the British bosom into a sufficiently tranquil state to discuss this great subject; for every Englishman's heart will begin bounding like a tremendous bonse, at the bare mention of trial by jury. ${ }^{123}$ Beckett continued with a reference to the ancient inheritance of Englishmen: "The trial by jury is of course a subject that every true-born Briton with a quarter of a pint of Saxon blood in his veins is prepared to revel in. ${ }^{2114}$ After observing that jurors were often befuddled by the arguments of counsel and that they sometimes tossed up to decide cases, Beckett built to his climax: 'Such is trial by jury! The bulwark in which John Bull can walk triumphantly, the buttress of our rights, the clothes-prop of our liberties, the cloak-pin of law, and the hat-peg of equity. ${ }^{115}$ In fewer than a hundred years, the jury had

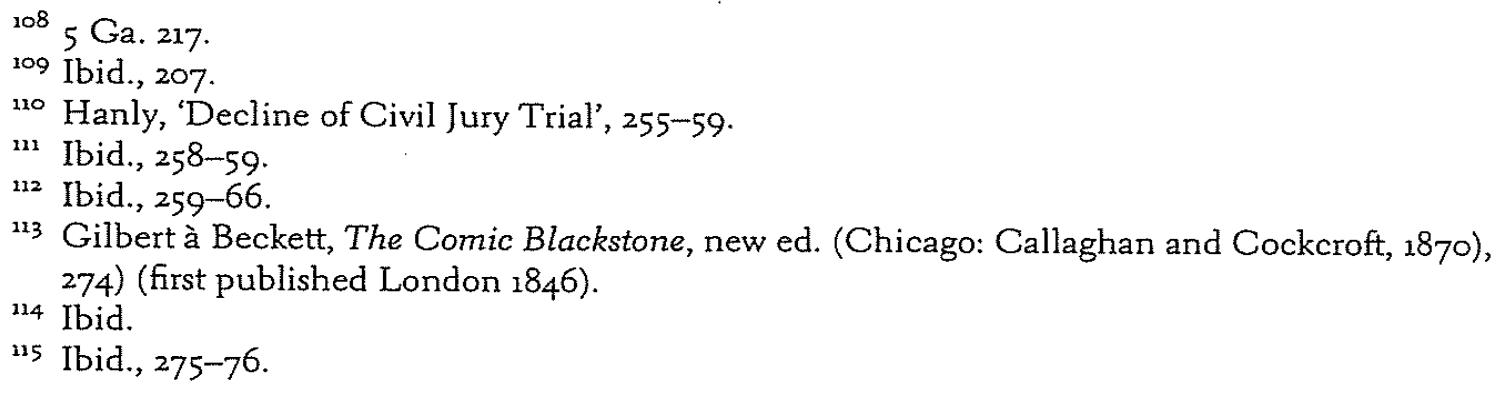


changed from a 'sacred palladium' to a figure of fun. Unhampered by a written constitutional guarantee of jury trial, England ultimately effectively abolished the civil jury and limited the criminal jury with the growth of summary jurisdiction. ${ }^{116}$ Constrained by their constitutions, American legislators and judges had to use more indirect ways to curtail the jury, including summary judgment and encouragement of settlement and plea bargaining. ${ }^{1{ }^{17}}$

\section{A TROUBLESOME INHERITANCE}

The story of the jury moving from an ancient and prized right of the people to a nuisance suggests the difficulties of constitutionalizing specific procedural rights concerning the legal system. Legal systems, economies, and politics can change, changing in turn the need or desire for a particular procedure. The idea of the jury as a right of Englishmen from time immemorial was a fiction: The criminal jury was unknown in 1215, and the barons at Runnymede insisted that the common law jury did not apply to them in the most important civil cases. The notion of the jury as an ancient right suited Coke in his struggles against royal prerogative in the seventeenth century, and Americans in their struggles against British control in the eighteenth century. After these battles were over, the civil jury seemed to many legal professionals and legislators to be a liability. The legal systems needed new procedures that were more efficient for commercial societies.

Part of the difficulty with constitutionalizing a particular procedure such as the late eighteenth-century jury is that the procedure was embedded in other procedures and institutions that were not constitutionalised. These other procedures and institutions underwent changes that inevitably affected jury trial. Examples of these changing procedures include the abolition of property requirements for jury service, the curtailment of judicial comment on the evidence in the United States and the shift to lawyer-conducted voir dire in the United States. Unless a constitution contains complete codes of civil and criminal procedure, the problem of changing associated procedures is inescapable.

There may be certain procedural rights that could be safely constitutionalised, but these would have to be basic to allow for appropriate change over time. Such basic rights might include adequate notice of the charges or claims against a defendant, and the evidence supporting them; the ability to respond; and adjudication by a reasonably impartial decision-maker. Of necessity,

${ }^{136}$ Hanly, 'Decline of Civil Jury Trial', 274-78.

${ }^{217}$ Lerner, 'Failure of Originalism', 845-69; John H. Langbein, 'The Disappearance of Civil Jury Trial in the United States', Yale Law Journal 122 (2012): 522, 542-72. 
many details of a legal system must be in the power of legislatures or courts to determine, to ensure that a legal system can adjust as needed to changes in technology, the economy and society.

Constitutionalizing a particular sort of decision-maker is especially problematic. The court of feudal tenants that the barons wanted to enshrine in Magna Carta was not suited to the later age of freeholds, nor is the civil jury suited to an age of commerce. England, without a written constitution specifying trial by jury, was able effectively to abolish the civil jury and to substitute a more efficient form of adjudication. The United States, hampered by jury rights in the federal and state constitutions, has had to resort to various inefficient manoeuvres to circumvent jury trial. Americans continue to pay for their invented inheritance. 